on chromosome structure and function in vertebrate cells. J. Cell Biol. 143:1575-1589.

5.Denizot, F. and R. Lang. 1986. Rapid colorimetric assay for cell growth and survival Modifications to the tetrazolium dye procedure giving improved sensitivity and reliability. J. Immunol. Methods 89:271-277.

6.Dinchuk, J.E., K.A. Kelley and G.N. Callahan. 1992. Flow cytometric analysis of transport activity in lymphocytes electroporated with a fluorescent organic anion dye. J. Immunol. Methods 155:257-265

7.Lukas, J., J. Bartek and M. Strauss. 1994 Efficient transfer of antibodies into mammalian cells by electroporation. J. Immunol. Methods 170:255-259.

8.Mir, L.M., H. Banoun and C. Paoletti. 1988 Introduction of definite amounts of nonpermeant molecules into living cells after electropermeabilization: direct access to the cytosol. Exp. Cell Res. 175:15-25.

9.Mir, L.M., L.F. Glass, G. Serša, J. Teissié, C. Domenge, D. Miklavčič, M.J. Jaroszeski, S Orlowski et al. 1998. Effective treatment of cutaneous and subcutaneous malignant tumors by electrochemotherapy. Br. J. Cancer 77:2336-2342.

10.Mir, L.M., O. Tounekti and S. Orlowski. 1996. Bleomycin: revival of an old drug. Gen. Pharmacol. 27:745-748.

11.Neumann, E., S. Kakorin and K. Toensing. 1999. Fundamentals of electroporative delivery of drugs and genes. Bioelectrochem. Bioenerg. 48:3-16.

12.Rols, M.P. and J. Teissié. 1998. Flow cytometry quantification of electropermeabilization. Methods Mol. Biol. 91:141-147.

13.Roper, P.R. and B. Drewinko. 1976. Comparison of in vitro methods to determine drug-induced cell lethality. Cancer Res. 36:2182-2188.

14.Saunders, J.A., C.H. Lin, B.H. Hou, J. Cheng, N. Tsengwa, J.J. Lin, C.R. Smith, M.S. McIntosh and S. Van Wert. 1995 Rapid optimization of electroporation conditions for plant cells, protoplasts, and pollen. Mol. Biotechnol. 3:181-90.

This work was supported in part by the CNRS, the Institut Gustave-Roussy, the University of Paris XI and by the Ministry of Science and Technology of the Republic of Slovenia. Address correspondence to $\mathrm{Dr}$. Lluis M. Mir, UMR 8532 CNRS, Institut Gustave-Roussy, 39 rue C. Desmoulins, F-94805 Villejuif, France.Internet: luismir@igr.fr

Received 8 November 1999; accepted 24 January 2000.

Tadej Kotnik ${ }^{1,2}$, Alenka

Maček-Lebar ${ }^{1}$, Damijan

Miklavčičr ${ }^{1}$ and Lluis M. Mir ${ }^{2}$

${ }^{1}$ University of Ljubljana

Ljubljana, Slovenia

${ }^{2}$ CNRS/Institut Gustave-Roussy

Villejuif, France

\section{Rapid Determination of Membrane Transport Parameters in Adherent Cells}

BioTechniques 28:926-932 (May 2000)

\section{ABSTRACT}

Reported here is a new method that permits rapid (approximately $5 \mathrm{~s}$ ) determinations of membrane transport phenomena in cells grown in monolayers at the base of 17-mm glass scintillation vials. The method is convenient, cost effective and requires no special apparatus. Initial uptake rates, steady-state and free substrate levels are demonstrated in ZR-75-1 breast cancer and Chinese hamster ovary cell lines using methotrexate, a model agent transported by the reduced folate carrier. The technique should be applicable to the study of the transport properties in a broad range of substrates and cells in monolayer culture.

\section{INTRODUCTION}

Membrane transport of physiological substrates and pharmacological agents plays an important role in determining subsequent anabolic or catabolic events within cells or as a determinant of drug activities. The careful characterization of transport properties (that is, influx kinetics and transmembrane gradients) is difficult to achieve when cells grow only under adherent culture conditions. In particular, it may not be possible to obtain uptake points rapidly enough to capture initial rates and ensure that uptake measurements are not complicated by the metabolism of the transport substrate or its export from cells.

Transport studies for cells in adherent cultures are usually performed in petri dishes or multi-well plates. Some methods have been developed that require special custom-made devices $(7,16)$. Besides being costly and complex, these techniques can be subject to fluctuations in incubation temperatures within the laboratory or they may require an ambient temperature of $37^{\circ} \mathrm{C}$. Hence, transport studies for adherent cells are often limited to single uptake points or long intervals with fewer time points $(12,14,15)$. This report describes a rapid, cost-effective method that simplifies the study of transport in cells in adherent culture, permits the study of early uptake points and allows a level of accuracy and precision that is necessary for the quantitative analysis of transport parameters under physiological growth conditions.

\section{MATERIALS AND METHODS}

\section{Materials}

Materials were obtained as follows: Iscove's Modified Dulbecco's Medium (IMDM) (HyClone, Logan, UT, USA); fetal bovine serum (Gemini BioProducts, Calabasas, CA, USA); trypsin (Life Technologies, Rockville, MD, USA); hygromycin B (CalbiochemNovabiochem, San Diego, CA, USA); methotrexate (MTX) (Lederle, Carolina, PR); $\quad\left[3^{\prime}, 5^{\prime}, 7^{\prime}-3 \mathrm{H}\right]$ methotrexate (Amersham Pharmacia Biotech, Piscataway, NJ, USA); low-background 17mm scintillation glass vials (Research Products International, Mt. Prospect, IL, and Fisher Scientific Pittsburg, PA,USA); 8-mL culture vials (Lawson Mardon Wheaton, Millville, NJ, USA); and BCA protein assay reagent kit (Pierce Chemical, Rockford, IL, USA).

\section{Cell Lines and Growth Conditions}

Wild-type ZR-75-1 (5) and the human RFC1-transfected MTX ${ }^{\mathrm{R}}$ ZR75/RFC1 human breast cancer cell lines (12) were maintained in $25-\mathrm{cm}^{2}$ culture flasks in IMDM supplemented with 5\% fetal bovine serum, $2 \mathrm{mM}$ L-glutamine, $100 \mathrm{U} / \mathrm{mL}$ penicillin and $100 \mu \mathrm{g} / \mathrm{mL}$ streptomycin. PYR $100 / \mathrm{RFC} 1$, a $\mathrm{CHO}$ cell line transfected with murine RFC1, was maintained in RPMI 1640 medium supplemented with $5 \%$ fetal bovine serum (1). Hygromycin B $(150 \mu \mathrm{g} / \mathrm{mL})$ was added to the growth medium of the transfected cells.

\section{Purification of Methotrexate}

Tritiated and nonlabeled MTX were purified by reverse phase HPLC as described previously (11). 


\section{Short Technical Reports}

\section{Measurement of Membrane Transport Parameters in Monolayer Cell Cultures}

Cells in monolayer cultures in $25-\mathrm{cm}^{2}$ flasks were trypsinized and resuspended to a final density of $10^{5}$ cells $/ \mathrm{mL}$ in their growth medium. One microliter of the cell suspension was added to 17-mm low-background glass scintillation vials (Eppendorf, Hamburg, Germany). The vials were loosely capped and left unshaken for about 10 min in an upright position to allow the cells to settle uniformly and adhere to the base before transfer to an incubator where they were maintained at $37^{\circ} \mathrm{C}$ in $5 \% \mathrm{CO}_{2}$. Cell lines growing at different rates were inoculated at a density that permitted mid-log phase (about $5 \times 10^{5}$ cells/vial) to be reached in 4-6 days. Confluence was monitored with an inverted microscope by placing an open vial on a thin glass slide or a petri dish on the microscope stage. Fine focusing at higher magnification was achieved by the use of a custom-made, inexpensive tube holder provided by Nikon
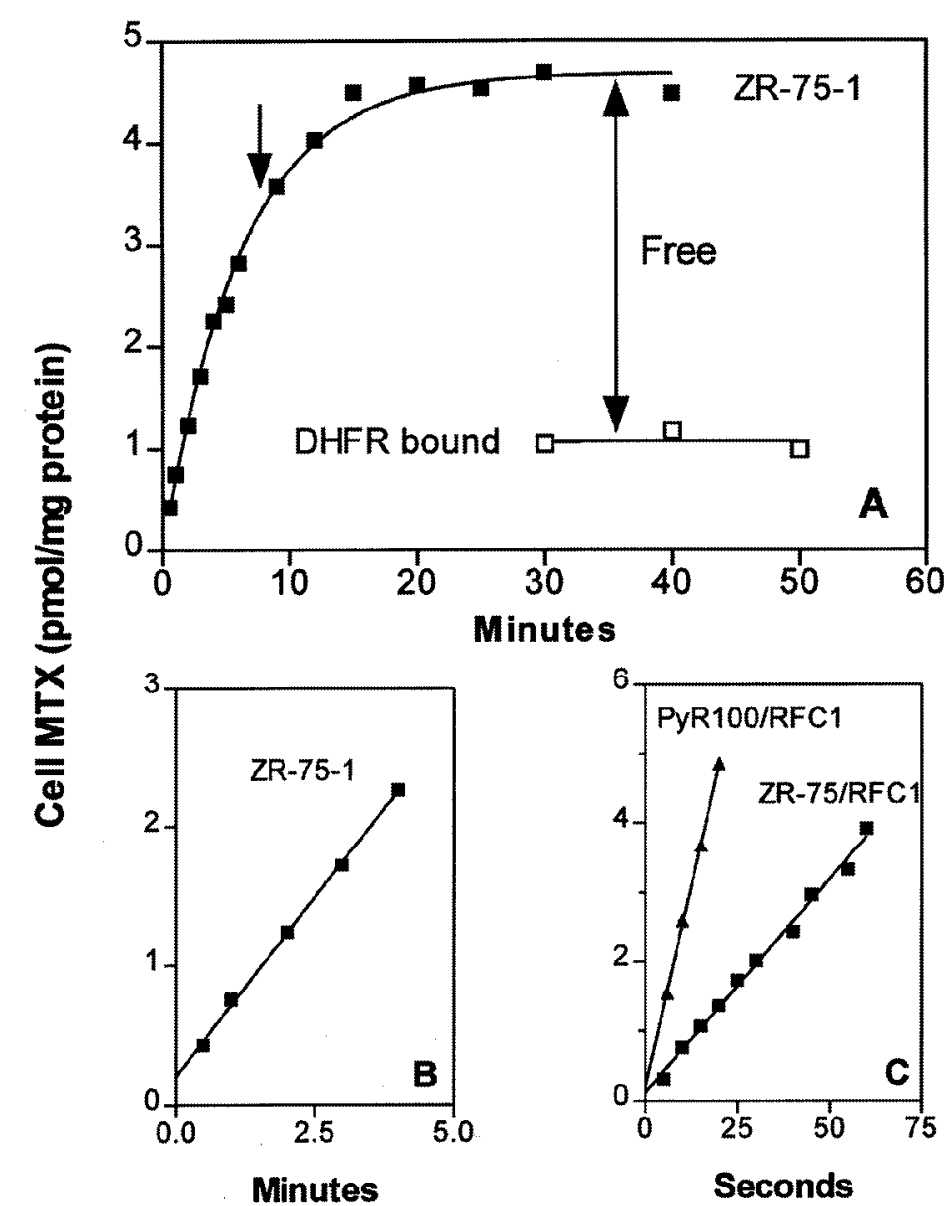

Figure 1. Initial rates and net uptake of MTX in adherent cell lines. (A) A time course of MTX uptake into ZR-75-1 human breast cancer cells (closed boxes). Cells were incubated with $0.5 \mu \mathrm{M}{ }^{3} \mathrm{H}-\mathrm{MTX}$ for the indicated intervals, and the uptake was assessed as described in Materials and Methods. Bound MTX levels (open boxes) were quantitated when the medium was replaced with MTX-free transport medium (at the arrow), and subsequent efflux continued to allow complete loss of free intracellular drug (doubleheaded vertical arrow). This figure is representative of five experiments performed on different days. (B) An expanded scale representation of the initial uptake component in Panel A representative of five experiments. (C) Initial uptake of MTX in CHO PYR ${ }^{100 / R F C 1 ~(c l o s e d ~ t r i a n g l e s) ~ a n d ~ M T X ~}{ }^{\mathrm{R}}-\mathrm{ZR}-75 / \mathrm{RFC} 1 \mathrm{hu}-$ man breast cancer cells (closed boxes), both transfected with RFC1. The data represents four and two experiments, respectively, performed on separate days. Extracellular ${ }^{3} \mathrm{H}-\mathrm{MTX}$ concentration was $1 \mu \mathrm{M}$.
(Melville, NY, USA). Vials were transferred to a $37^{\circ} \mathrm{C}$ water bath before uptake studies.

Transport measurements were initiated after aspiration of growth medium and the addition of $300 \mu \mathrm{L}$ prewarmed transport medium IMDM and $20 \mathrm{mM}$ HEPES ( $\mathrm{pH}$ 7.4) equilibrated with $\mathrm{CO}_{2}$ containing the transport substrate ${ }^{3}$ H-MTX (specific activity 1000-2000 or $300-400 \mathrm{dpm} / \mathrm{pmol}$ for extracellular MTX concentrations of 0.5 or $10 \mu \mathrm{M}$, respectively). Uptake was stopped by placing the vial in ice, followed by the rapid yet careful addition of $6 \mathrm{~mL}$ ice-cold PBS (pH 7.4) against the side of the vial so not to disrupt the attached cell monolayer. For measurement of the nonexchangeable fraction of intracellular MTX, cells were incubated with ${ }^{3} \mathrm{H}-\mathrm{MTX}$ for $10 \mathrm{~min}$ to generate free intracellular drug. Then the medium was removed rapidly by aspiration and replaced with $2 \mathrm{~mL}$ prewarmed MTXfree transport medium. Incubation was continued to allow efflux of all the free intracellular drug.

Cells were then processed by aspiration of the medium and the addition of $6 \mathrm{~mL}$ ice-cold PBS. The cells were then subjected to three additional washes by gentle swirling, followed by aspiration. The vials were placed at an angle in an ice-water bath for 5-10 min to collect and aspirate the residual washing buffer. Cells were then lysed with 0.5 $\mathrm{mL} 0.2 \mathrm{~N} \mathrm{NaOH}$ at $65^{\circ} \mathrm{C}$ for $30 \mathrm{~min}$; $400 \mu \mathrm{L}$ lysate were then used to determine intracellular radioactivity in a liquid scintillation spectrometer. Total protein for each sample was determined on a $10-\mu \mathrm{L}$ portion of the lysate by the BCA protein assay reagent kit and ranged from $80-100 \mu \mathrm{g} / \mathrm{vial}$. Data were converted to pmol MTX/vial and subsequently normalized with total protein to determine intracellular MTX in $\mathrm{pmol} / \mathrm{mg}$ protein.

\section{RESULTS AND DISCUSSION}

The reduced folate carrier $\left(\mathrm{RFCl}^{3}\right)$, a member of the facilitator superfamily of carriers (13), is an anion exchanger that mediates uphill transport of reduced folates and the folate analog MTX into eukaryotic cells $(2,4,8-10)$. A method was developed to study 


\section{Short Technical Reports}

transport in ZR-75-1 human breast cancer and other cell lines that grow well in monolayer but not in suspension culture. Figure $1 \mathrm{~A}$ illustrates a time course of MTX uptake into these cells using the technique described here. Initial rates of MTX uptake remain constant for 3-4 min, and steady state is achieved in about $20 \mathrm{~min}$. On replacement of the transport medium with drug-free medium, free MTX exits the cells, and both MTX bound to DHFR and free drug can be distinguished.

Figure 1B is an expanded scale representation of the initial uptake component from panel A with cell MTX monitored at 30 and $60 \mathrm{~s}$ and then at 1-min intervals. The mean initial rate was $0.603 \mathrm{pmol} / \mathrm{mg}$ protein $/ \mathrm{min}$ with an average SEM of $\pm 0.036 \mathrm{pmol} / \mathrm{mg}$ protein/min based on an analysis of five separate experiments.

The MTX $^{\mathrm{R}}$ ZR-75/RFC1 line was derived by transfection of human RFC1
cDNA into transport-deficient $\mathrm{MTX}^{\mathrm{R}}$ ZR-75-1 cells (3). In these cells, the initial uptake phase is more rapid, and uptake measurements over very brief intervals must be obtained to capture initial rates.

Figure 1C illustrates the initial uptake in MTX ${ }^{\mathrm{R}}$-ZR-75/RFC cells with uptake points measured every $5 \mathrm{~s}$. Also seen is an uptake of MTX in the PYR ${ }^{100 / R F C ~ C H O ~ c e l l ~ l i n e, ~ a l s o ~ t r a n s-~}$ fected with RFC1, in which the initial rate is considerably faster. The linearity of uptake is apparent with ordinate intercepts close to the point of origin for both cell lines. For the PYR 100/RFC cells, the average influx was $12.9 \mathrm{pmol} /$ $\mathrm{mg}$ protein/min with an average SEM of $\pm 1.26 \mathrm{pmol} / \mathrm{mg}$ protein $/ \mathrm{min}$ based on an analysis of four separate experiments. Hence, the SEM of the influx measurements is only $\pm 10 \%$. These measurements have been successfully recorded over a wide range $(0.5-10 \mu \mathrm{M})$ of extra- cellular MTX concentrations.

This method requires that cell cultures be at mid-log phase at the time of transport determinations. Initial uptake rates were reduced by a factor of three in overgrown cell cultures because of the reduced viability of the cells or the down-regulation of RFC1. In cultures at low density $\left(<3 \times 10^{5}\right.$ cells/vial $)$, there is inadequate radioactivity and loss of accuracy.

The assay uses only a small number of cells (about $5 \times 10^{5}$ ) per uptake point; hence, it requires a relatively high specific activity of radiolabeled MTX (1000-2000 dpm/pmol for lower concentrations and 300-400 dpm/pmol for higher, extracellular concentrations). This is in contrast to uptake in suspensions where greater than $10^{7}$ cells are used per uptake point; under these conditions, an MTX-specific activity of $100-300 \mathrm{dpm} / \mathrm{pmol}$ is sufficient. Since only a small volume of transport medi- 
um per uptake point is needed with this method, transport parameters can be determined at a variety of concentrations of substrates and inhibitors even when quantities available are limited. Similarly, the medium can be modified to study other factors that may influence transport such as ionic composition, $\mathrm{pH}$, energy dependence and so forth.

The method reported here represents a small but important refinement of current approaches to the measurement of transport in cells growing in monolayer culture. The use of vials instead of welled plates permits rapid manipulation of cells, increased numbers of uptake points over brief intervals plus a level of accuracy that is critical for quantitative transport studies. Also, glass vials provide better thermal conductance than plastic and rapidly stop transport on immersion at $4^{\circ} \mathrm{C}$. The method is quite cost effective; only small volumes of media and radiochemical agents are necessary, and no special devices are needed.
Transport parameters can be determined over a wide range of substrate concentrations $(0.5-10 \mu \mathrm{M})$ and conditions. The vials are easy to handle and fit into a water bath, which allows a constant temperature to be maintained within the laboratory setting. Subsequent washing and preparation for analyses are simplified. The method permits highly quantitative transport studies on monolayer cultures without forcing cells to grow in suspension where transport and metabolic processes might be perturbed (6). The technique is, however, dependent on the vials used. For example, cells adhere and grow in glass scintillation vials from Research Product International and culture vials from Wheaton Science Products, but did not grow in the tested lot of glass scintillation vials from Fisher Scientific. The basis for this difference is not clear, and we have not attempted to evaluate a broad range of products or lots to determine which ones are or are not suitable.

\section{REFERENCES}

1.Assaraf, Y.G. and I.D. Goldman. 1997. Loss of folic acid exporter function with markedly augmented folate accumulation in lipophilic antifolate-resistant mammalian cells. J. Biol. Chem. 272:17460-17466.

2.Brigle, K.E., M.J. Spinella, E.E. Sierra and I.D. Goldman. 1995. Characterization of a mutation in the reduced folate carrier in a transport defective L1210 murine leukemia cell line. J. Biol. Chem. 270:22974-22979.

3.Cowan, K.H. and J. Jolivet. 1984. A methotrexate-resistant human breast cancer cell line with multiple defects, including diminished formation of methotrexate polyglutamates. J. Biol. Chem. 259:10793-10800.

4.Dixon, K.H., B.C. Lanpher, J. Chiu, K. Kelley and K.H. Cowan. 1994. A novel cDNA restores reduced folate carrier activity and methotrexate sensitivity to transport deficient cells. J. Biol. Chem. 269:17-20.

5.Engel, L.W., N.A. Young, T.S. Tralka, M.E. Lippman, S.J. O'Brien and M.J. Joyce. 1978. Establishment and characterization of three new continuous cell lines derived from human breast carcinomas. Cancer Res. 38:3352-3364.

6.Foster, D.O. and A.B. Pardee. 1969. Transport of amino acids by confluent and nonconfluent 3T3 and polyoma virus-transformed $3 \mathrm{~T} 3$ cells growing on glass cover slips. J. Biol. Chem. 244:2675-2681.

7.Gazzola, G.C., V. Dall'Asta, R. FranchiGazzola and M.F. White. 1981. The clustertray method for rapid measurement of solute fluxes in adherent cultured cells. Anal. Biochem. 115:368-374.
8.Goldman, I.D. 1971. The characteristics of the membrane transport of amethopterin and the naturally occurring folates. Ann. NY Acad. Sci. 186:400-422.

9.Goldman, I.D., N.S. Lichtenstein and V.T. Oliverio. 1968. Carrier-mediated transport of the folic acid analogue methotrexate, in the L1210 leukemia cell. J. Biol. Chem. 243:5007-5017.

10.Henderson, G.B. and E.M. Zevely. 1983. Structural requirements for anion substrates of the methotrexate transport system of L1210 cells. Arch. Biochem. Biophys. 221:438-446.

11.Matherly, L.H., C.K. Barlowe, V.M. Phillips and I.D. Goldman. 1987. The effects of 4-aminoantifolates on 5-formyltetrahydrofolate metabolism in L1210 cells. J. Biol. Chem. 262:710-717.

12.Moscow, J.A., M.K. Gong, R. He, M.K. Sgagias, K.H. Dixon, S.L. Anzick, P.S. Meltzer and K.H. Cowan. 1995. Isolation of a gene encoding a human reduced folate carrier $(R F C 1)$ and analysis of its expression in transport-deficient, methotrexate-resistant human breast cancer cells. Cancer Res. 55:37903794.

13.Pao, S.S., I.T. Paulsen and M.H. Saier, Jr. 1998. Major facilitator superfamily. Microbiol. Mol. Biol. Rev. 62:1-34.

14.Saito, H., S. Masuda and K. Inui. 1996. Cloning and functional characterization of a novel rat organic anion transporter mediating basolateral uptake of methotrexate in the kidney. J. Biol. Chem. 271:20719-20725.

15.Saito, H., M. Yamamoto, K. Inui and R. Hori. 1992. Transcellular transport of organic cation across monolayers of kidney epithelial cell line LLC-PK. Am. J. Physiol. 262:C59C66.

16.Slaughter, R.S. and E.M. Barnes, Jr. 1981. Rapid sampling method for measuring uptake of small molecules by cultured cell monolayers. Anal. Biochem. 117:67-69.

This work was supported by National Cancer Institute grant no. CA-39807 to IDG. Address correspondence to Dr. I. David Goldman, Director, Comprehensive Cancer Center, Albert Einstein College of Medicine, Chanin Two, 1300 Morris Park Avenue, Bronx, NY, 10461 USA. Internet: igoldman@aecom.yu.edu

Received 23 June 1999; accepted 7 January 2000.

\author{
Karim A. Sharif and I. David \\ Goldman \\ Albert Einstein College \\ of Medicine \\ Bronx, NY, USA
}

